\title{
LIME DISSOLUTION IN SIMULATED INITIAL STAGE OF BOF PROCESS*
}

\section{Resumo}

\author{
Ludimila Melo Vieira ${ }^{1}$ \\ Henrique Silva Furtado ${ }^{2}$ \\ Heitor Cristo Clem de Oliveira ${ }^{3}$ \\ Anna Paula Littig Berger ${ }^{4}$ \\ Silas Gambarine Soares ${ }^{5}$ \\ José Roberto de Oliveira ${ }^{6}$
}

O foco deste estudo é avaliar a capacidade de dissolução das partículas de cal a uma temperatura próxima da fase inicial de sopro do processo BOF. Os testes foram realizados em um forno elétrico utilizando amostras de Cal com diâmetros de $6 \mathrm{~mm}$ e 9 $\mathrm{mm}, 80 \%$ e $100 \%$ calcinadas em diferentes basicidades de escoria. Os resultados mostram que com o menor nível de calcinação a dissolução foi mais rápida. Podendo ser atribuído a algumas diferenças na porosidade da cal ou um efeito de formação de espuma observado durante os testes devido à evolução do CO2 da calcinação restante. O aumento na basicidade da escória resultou na redução da taxa de dissolução que pode ser atribuída a uma precipitação de fase sólida mais densa na interface das partículas aumentando a viscosidade da escória e reduzindo a porosidade da partícula. A partir de um modelo de regressão linear o nível de calcinação mostrou maior efeito sobre o coeficiente cinético do processo de dissolução seguido do tamanho de partícula. $\mathrm{O}$ efeito mais fraco foi a basicidade da escória. Este resultado sugere que a área de contato cal escória parece ser mais significativa do que a viscosidade no processo de dissolução de cal nos presentes experimentos.

Palavras-chave:Dissolução da Cal; Granulometria; Calcinação Cal; Basicidade.

\section{Abstract}

\section{LIME DISSOLUTION}

The focus of this study is to evaluate the dissolution ability of different lime particles size and calcination levels submitted to different slag chemistry, at temperature close to that of early stage of BOF process blowing time. Tests conducted in a small electrical furnace using lime samples of $6 \mathrm{~mm}$ and $9 \mathrm{~mm}$ particle size and $80 \%$ and $100 \%$ calcinated at different slag basicity reported results showing that lower lime calcination level produced the faster dissolution process. These results might be attributed to some differences in lime porosity or a foaming effect observed during the testes due to $\mathrm{CO} 2$ evolution of remaining calcination. The increase of slag basicity resulted in reduction of lime dissolution rate, which might be attributed to a denser solid phase precipitation at the interface lime particle-slag that might increase slag viscosity as well reduce particle porosity. From a multilinear regression model, lime calcination level showed the strongest effect on kinetic coefficient of lime dissolution process, followed by particle size. The weaker effect was from slag basicity. This result suggests that lime-slag contact area seems to be more significant than viscosity in the lime dissolution process of present experiments.

Keywords: Lime Dissolution; Particle Size; Lime Calcination; Basicity.

1 Engenheira Metalurgista e Mestranda em Engenharia Metalúrgica e de Materiais, Instituto Federal do Espírito Santo (IFES), Vitória, ES, Brasil.

2 Engenheiro Metalurgista, MsC, PhD, Especialista de pesquisa e desenvolvimento, Centro de pesquisa da ArcelorMittal para a américa do sul.

3 Mestre em Engenharia Metalúrgica e de Materiais, IFES, Vitória, ES, Brasil.

4 Eng. Metalurgista e Mestranda em Eng. Metalúrgica e de Materiais, IFES, Vitória, ES, Brasil.

5 Mestre em Engenharia Metalúrgica e de Materiais, IFES, Vitória, ES, Brasil.

6 Prof. Dr. do Instituto Federal do Espírito Santo, IFES, dos cursos de graduação e pós-graduação em Engenharia Metalúrgica e de Materiais. 


\section{INTRODUCTION}

Lime dissolution during BOF process has being investigated through a collaborative work between RDBR (12ำ ArcelorMittal research center) and IFES. It involves the usage of laboratories and human resources from IFES (Federal Institution of Espirito Santos state) through a research contract with FACTO (Foundation for supporting the development of science and technology), partially sponsored by recent created EMBRAPII, a federal institution that has the mission to stimulate CompaniesUniversity joined research.

The focus of this study is to evaluate the dissolution ability of two different lime particles size with two different levels of calcination each, submitted to different slag chemistry, at temperature close to that of early stage of BOF process blowing time.

This initiative was carried out to give support to more comprehensive studies that aim at producing very low point $P$ in steel ( lower than 60ppm), as well as reducing BOF slopping and oxygen lance scull build up occurrences.

\section{METHODOLOGY}

Some limestone collected from Tubarão steel plant with the composition presented in Table I was used to prepare limes particles at IFES laboratory.

Table I - Limestone used as a raw material for lime production at IFES laboratory.

\begin{tabular}{ccccccc}
\hline & $\mathrm{CaCO}_{3}$ & $\mathrm{SiO}_{2}$ & $\mathrm{Al}_{2} \mathrm{O}_{3}$ & $\mathbf{S}$ & $\mathbf{P}$ & $\begin{array}{c}\text { Moisture } \\
\text { max }\end{array}$ \\
\hline Limestone & 96,86 & 1,32 & 0,18 & 0,047 & 0,046 & 3,0 \\
\hline
\end{tabular}

Two levels of limestone calcination were arbitrary defined as $100 \%$ and $80 \%$ for the two particle sizes also arbitrary defined as 6 and $9 \mathrm{~mm}$.

Calcination times to reach the above calcination level was previously defined by a set of calcination tests performed at $950^{\circ} \mathrm{C}^{[1]}$ summarized in figure 1 .

In order to avoid lime deterioration effects in tests, only the material necessary of each teste was previously produced. In this case, the lime was kept inside the furnace which temperature dropped from the calcination one to $250^{\circ} \mathrm{C}$ for 30 second just before its utilization in dissolution testes.

Slag chemistry used in dissolution testes at $1400^{\circ} \mathrm{C}$ is presented in table II. They were defined from literature studies of BOF slag evolution during the early stage of oxygen blow ${ }^{[2]}$. Some properties were estimated through software FactSage 7.0 calculation (table III). These compositions were produced using high purity oxides except $\mathrm{CaO}$ that was from experimental lime particles. 

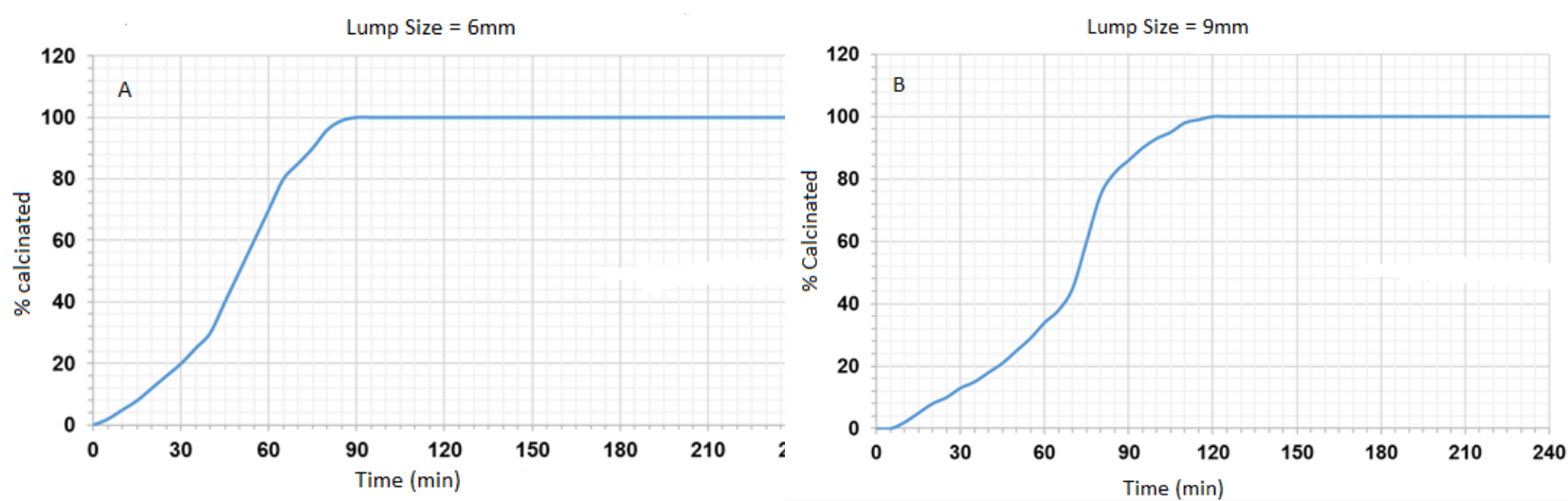

Figure 1: Limestone calcination curves

Table II - Final slag composition aimed for dissolution tests.

\begin{tabular}{cccccc}
\hline & \multirow{2}{*}{ Basicity } & \multicolumn{4}{c}{ Chemical Composition (\%By weight) } \\
\cline { 3 - 6 } \cline { 3 - 6 } Slag & & $\mathrm{CaO}$ & $\mathrm{SiO}_{2}$ & $\mathrm{FeO}$ & $\mathrm{MgO}$ \\
\hline 1 & 1,25 & 35 & 28 & 33 & 4 \\
2 & 2 & 35 & 17,5 & 43,5 & 4 \\
3 & 3 & 35 & 11,67 & 49,33 & 4 \\
4 & 4 & 35 & 8,75 & 52,25 & 4 \\
\hline
\end{tabular}

Table III - Some predicted slag properties at $1400^{\circ} \mathrm{C}$.

\begin{tabular}{cccc}
\hline \multirow{2}{*}{ Basicity } & \% Liquid & \% de Solid & \multirow{2}{*}{ aCaO } \\
\cline { 3 - 3 } & 100,00 & MgO & 0,05 \\
2,25 & 100,00 & 0,00 & 0,18 \\
3,00 & 99,57 & 0,00 & 0,37 \\
4,00 & 98,93 & 0,43 & 0,51 \\
\hline
\end{tabular}

Lime dissolution tests were performed in a $3 \mathrm{Kg}$ electrical resistance furnace with inert atmosphere as illustrated by figure 2 .

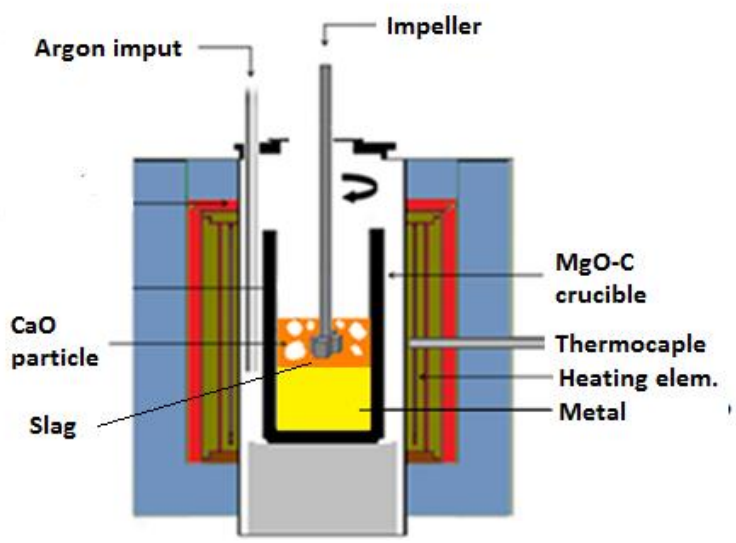

Figure 2: Lime dissolution experimental set up.

The experimental set up was design to use an especial hot metal, previously produced from a re-carburization of steel. This strategy was adopted in order to avoid 
test contamination as well as to obtain a better thermal control of dissolution experiments. After $997 \mathrm{~g}$ of metal melt at $1400^{\circ} \mathrm{C}$, slag forming materials (total of 50 gr) were added and the crucible was homogenized for 2 minutes using an impeller rotating at 400rmp.

With the slag homogenized and temperature stabilized, lime particles $(17.5 \mathrm{~g})$ were added and kept under the same impeller mixing speed for more 5 minutes, period during which two slag samples were taken at 2.5 minutes time steps. Table IV summarize all the steps of present 20 dissolution experiments.

Slag sample was crushed and washed in water to measure non dissolved lime. Due to the small amount of slag it was not possible to perform elemental chemical analysis.

Table IV - Steps of lime dissolution experiments

\begin{tabular}{cc}
\hline Tempo $(\min )$ & Procedures \\
\hline- & Temperature tunning \\
0 & Slag forming addition \\
2 & Lime addition \\
4,5 & Slag sampling \\
7 & Slag sampling \\
\hline
\end{tabular}

\section{RESULTS AND ANALYSIS}

Table $\mathrm{V}$ summarizes the results of non-dissolved lime of all the experiments obtained by hydration of slag samples. Table VI presents the results of dissolved lime after dehydration (draying). Both results are comparable as observed by figure 3, which show a consistency between them.

Table V - Summary of lime dissolution experimental results.

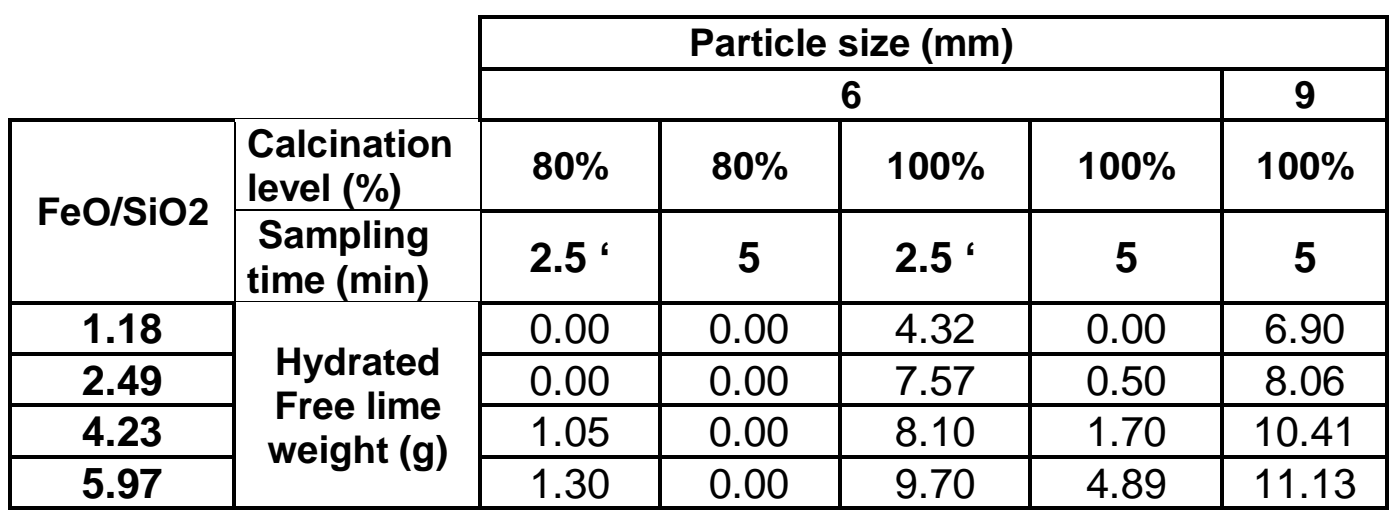


Tabela 1 - Percentage of lime dissolved in slag.

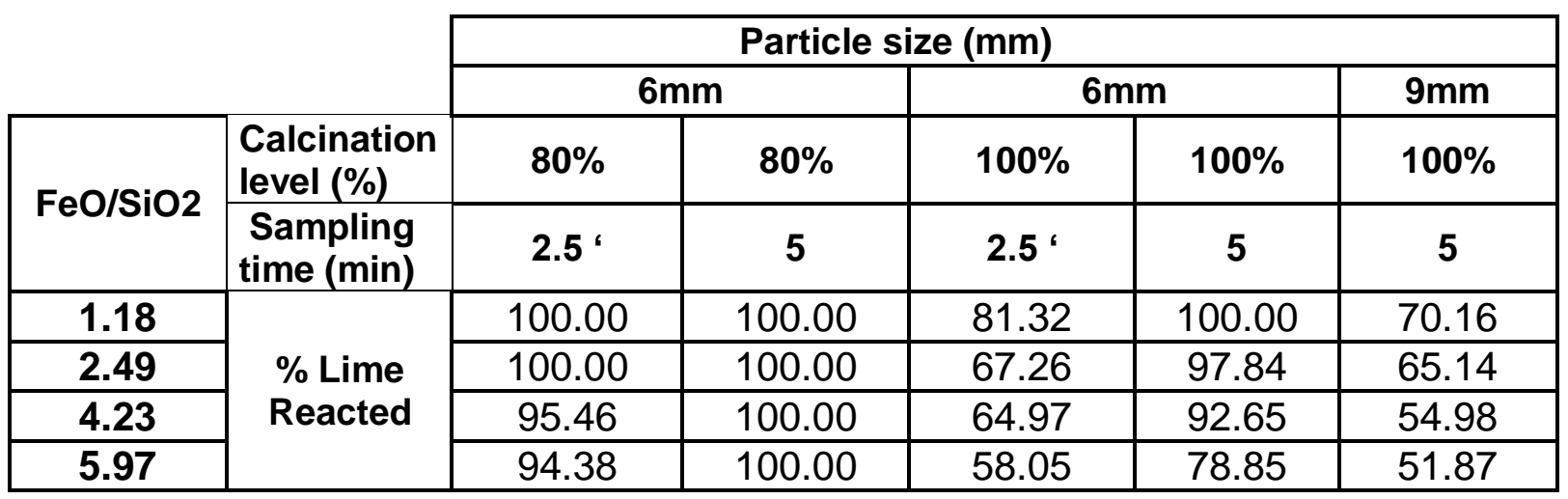

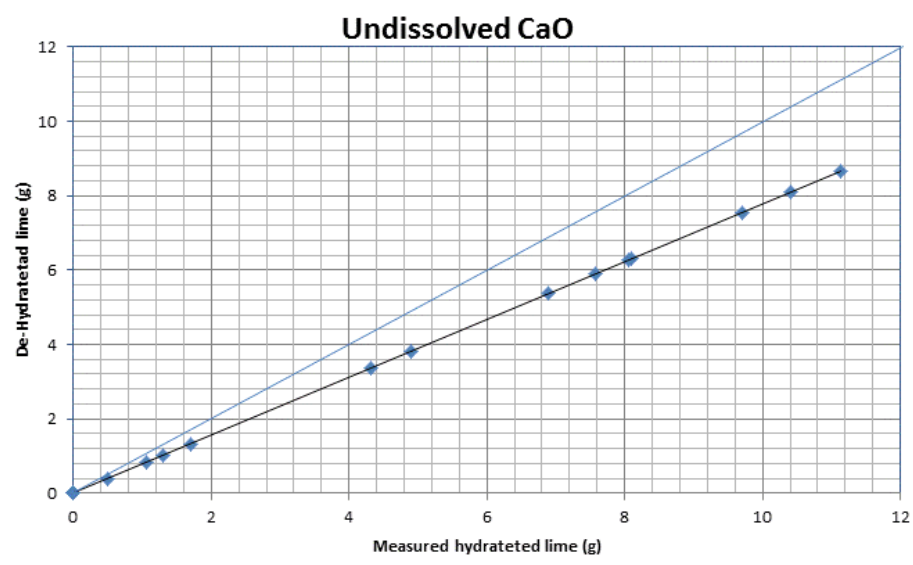

Figure 3: Comparison of non-dissolved $\mathrm{CaO}$ obtained from two different methods

Figure 4 summarize the results of dissolution tests. Faster dissolution was found from lower calcination level ( $80 \%$ Calcinated lime), lowers initial $\mathrm{FeO} / \mathrm{SiO} 2$ slag relation and lower particle size.

Lime dissolution process is a well-known solid-liquid interfacial phenomenon where de $\mathrm{Ca}+$ dissolution rate seems to be regulated by diffusion mechanism in a solidliquid boundary layer, where more dense solid phase precipitation in lime surface is reported to impair dissolution rate by their effect on reducing liquid solid interface area and diffusivity ${ }^{[3]}$. Also, some slag properties like viscosity and interfacial tension might influence liquid infiltration inside lime particle porous. 


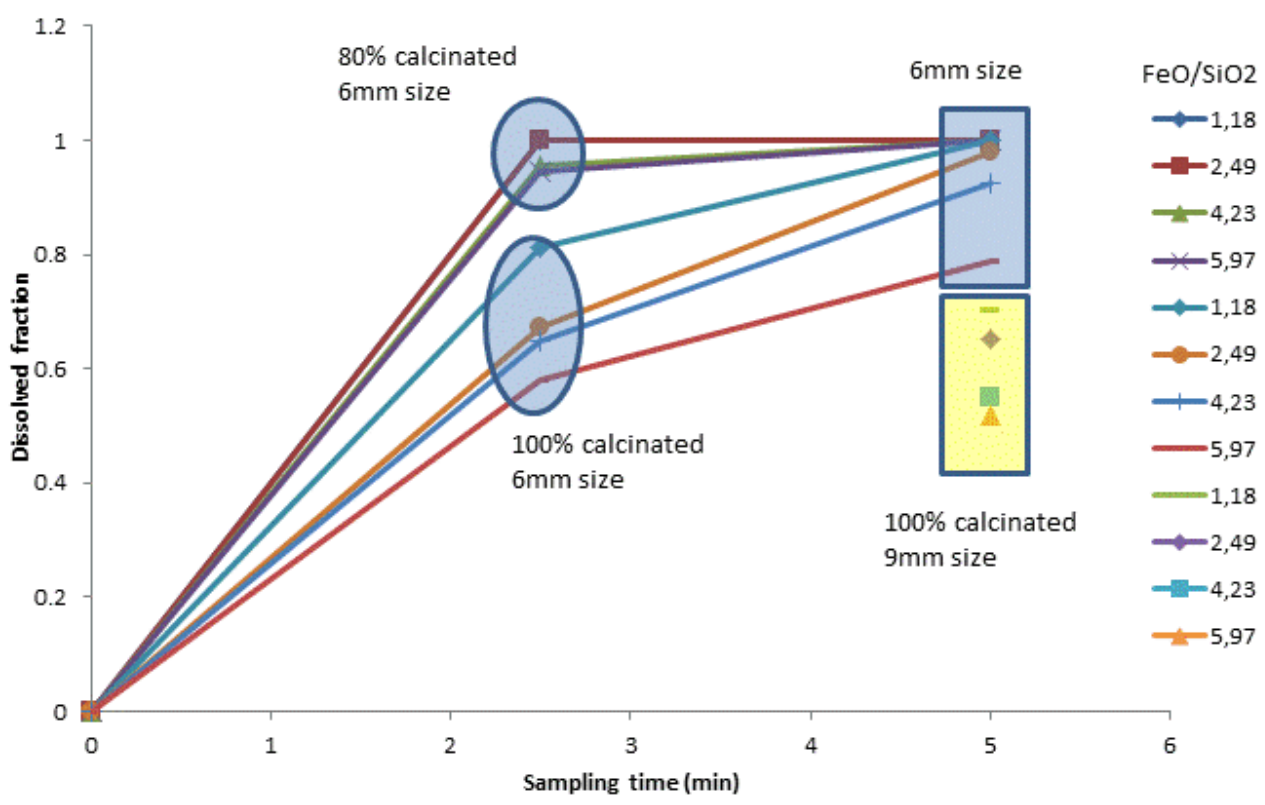

Figure 4: Summary of lime dissolution experiments

From thermodynamic point of view, some results from calculation obtained using CEQCSI software predict that the increase of $\mathrm{FeO} / \mathrm{SiO} 2$ relation might result in solid phase precipitation like: $3 \mathrm{CaO} . \mathrm{SiO} 2(\mathrm{C} 3 \mathrm{~S})$ and $(\mathrm{Mg}, \mathrm{Fe}) \mathrm{O}$ solid solution (MGW) which is summarized in figure 5 .

These results motivates speculation that there might be two control mechanism affecting lime dissolution: one related to the more dense shell formation around lime particle by C3S precipitation and the other due to the change in liquid slag properties, like viscosity or interfacial tension that would reduce slag infiltration into solid phases.

In fact, simulation results from CEQCSI show also that solid fraction precipitation at higher $\mathrm{FeO} / \mathrm{SiO} 2$ rate increase slag viscosity significantly (figure 6). This approach however was not predicted by Factage 7.0 calculation, which reported a lower value of viscosity.

For the possible mechanism presented above, a $100 \%$ liquid slag prediction would be not consistent to the reduction of lime dissolution observed in experiments associated to the increase of $\mathrm{FeO} / \mathrm{SiO} 2$ slag ratio, unless some effect of increasing surface tension could takes place and reduce liquid slag wetting to lime particles. 


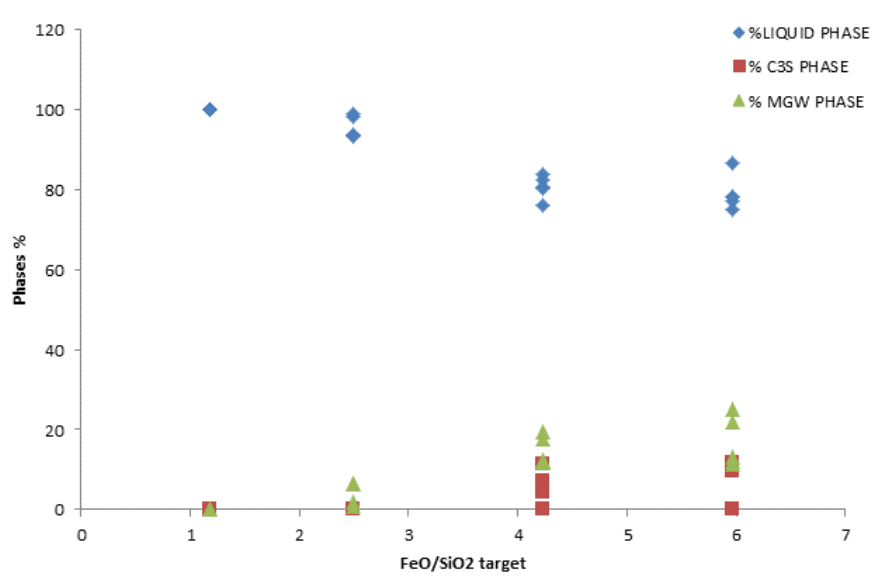

Figure 5: Some predictions of phase's precipitation in function of $\mathrm{FeO} / \mathrm{SiO} 2$ relation.

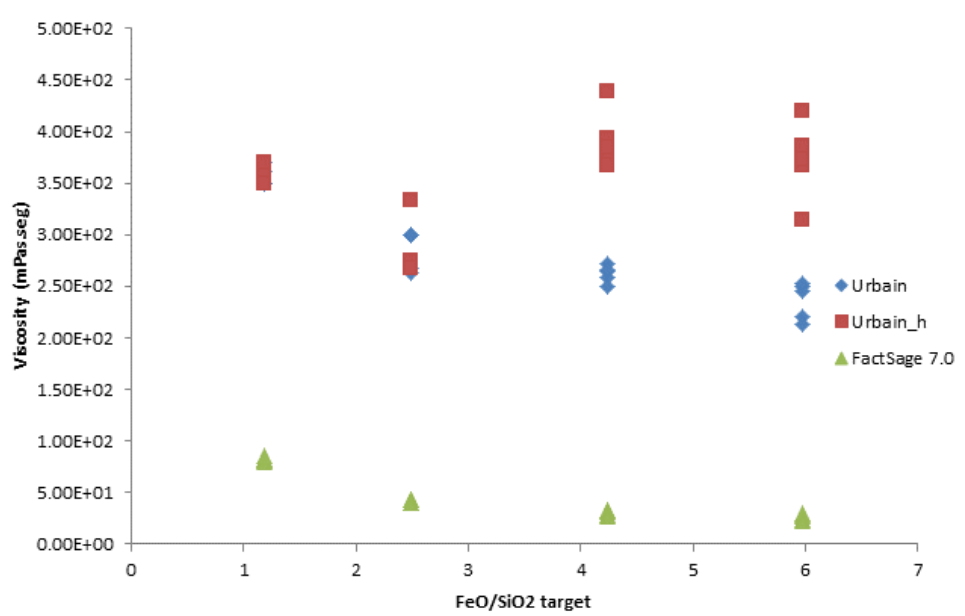

Figure 6: Prediction of slag viscosity: Urbain $\rightarrow$ liquid slag; Urbain_h $\rightarrow$ all slag phases

It is important to note that there is a relationship between $\mathrm{FeO} / \mathrm{SiO} 2$ ratio and Basicity $(\mathrm{CaO} / \mathrm{SiO} 2)$ as presented in figure 7 . Therefore and increase in $\mathrm{FeO} / \mathrm{SiO} 2$ is mainly imposed by the reduction of $\mathrm{SiO} 2$ that, for the same amount of added $\mathrm{CaO}$, will result in an increase of basicity which explain the C3S precipitation.

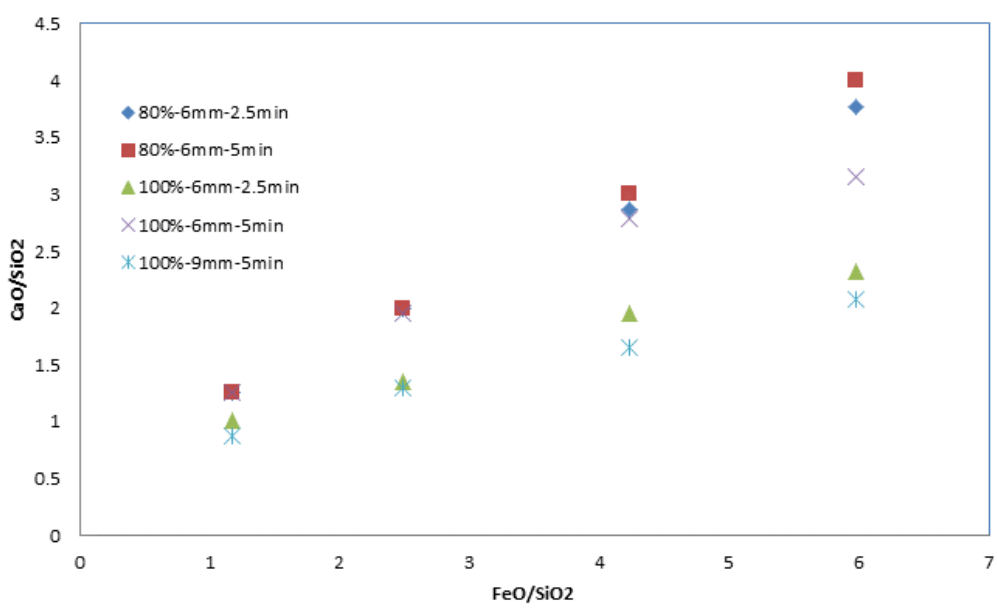

Figure 7: Relation between $\mathrm{FeO} / \mathrm{SiO} 2$ and basicity 
The results of presents experiments suggests that, in conditions where $\mathrm{SiO} 2$ regeneration from hot metal $\mathrm{Si}$ is low, lime dissolution behavior would be hindered by the increase of basicity at lower $\mathrm{T}$ in condition where $\mathrm{FeO}$ content is still low. Therefore in order to speed up slag formation, some silica should be added to keep the basicity under a certain low level as well as a soft blowing practice should be adopted to increase $\mathrm{FeO}$ content in slag.

On the contrary, at high hot metal $\mathrm{Si}$, basicity is low and therefore lower $\mathrm{FeO}$ is sufficient to keep higher lime dissolution rate, so hard blow strategy is enough to get good slag formation without excessive increase slag volume.

The above discussions have been oriented by thermodynamic calculation, which have some inaccuracy. Therefore in order to validate it some microscope analysis of undissolved lime residues should be performed.

Another important result extracted from figure 4 is the clear influence of calcination level of lime in its dissolution rate in slag. It was already documented that with the increase of calcination level there is a tendency for lime particle to increase density. Therefore, lime porosity would be reduced with the increase of calcination level and, as a consequence, less slag infiltration in lime particles would be expected and so lower dissolution rate. However, it was also observed that the remaining carbonation during dissolution test generated a higher foam slag due to the $\mathrm{CO} 2$ evolution. This effect can improve dissolution rate through the increase of $\mathrm{Ca}+$ diffusion in lime-slag boundary lower. Therefore without a close view on the effect of calcination level in lime porosity it is impossible to identify the actual phenomenon that increased lime dissolution rate a lower calcination level.

It seems that endothermic characteristic of calcination process that would provoke a drop in temperature around lime particle is probably being dispersed very fast, avoiding an increase of slag viscosity locally close do dissolution front.

Going back to figure 4, the effect of increasing particle size is straightforward explained by the reduction of specific contact area. In fact lager particle size with similar porosity will offer to the dissolution front a smaller area.

From experimental data it is possible to tune a kinetic model. The classic model described by equation 1 was used:

$$
\frac{d W}{d t}=k \cdot\left(a_{00}-1\right)
$$

Where $W$ is lime weight $(\mathrm{Kg}), t$ is time $(\mathrm{min}), K$ is coefficient $(\mathrm{Kg} / \mathrm{min})$ and $a$ is $\mathrm{CaO}$ activity.

This model states that dissolution rate (loss of lime weight $(\mathrm{W})$ with time $(\mathrm{t})$ ) of certain weight of $\mathrm{CaO}$ (lime) is monotonically related to the difference between $\mathrm{CaO}$ activity in slag (reference state as pure $\mathrm{CaO}$ ) and its value at hypothetical $\mathrm{CaO}$ saturation where its activity would be equal to one, modulated by a coefficient ( $k$ ) that introduce the interfacial solid-liquid resistance to the dissolution process (boundary layer effect). 
The integration of equation 1 produces the following expression:

(2),

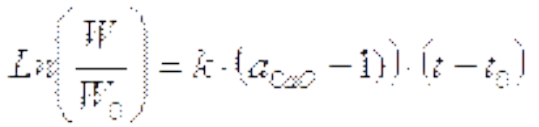

where the subscript $\mathrm{W} 0$ means the weight beginning of lime addition test $(\mathrm{Kg}), \mathrm{W}$ is lime weight $(\mathrm{Kg})$, $\mathrm{t}$ is time $(\mathrm{min})$, t0 is time started the addition, $K$ is kinetic coefficient $(\mathrm{Kg} / \mathrm{min})$ and $a$ is $\mathrm{CaO}$ activity.

Using the experimental data we can predict $\mathrm{k}$ from equation 2as shown in figure 8 for different basicity. From these results, a statistical model was built (a multi-linear model) relating " $k$ " to the trials conditions variables as basicity; particle size and calcination level of lime. The summary of regression coefficients and others statistical tests are shown in table VIII. The adjusted R square is 98.52 with a very low $p$-value which means a very good adjustment of this model to the data (figure 9).
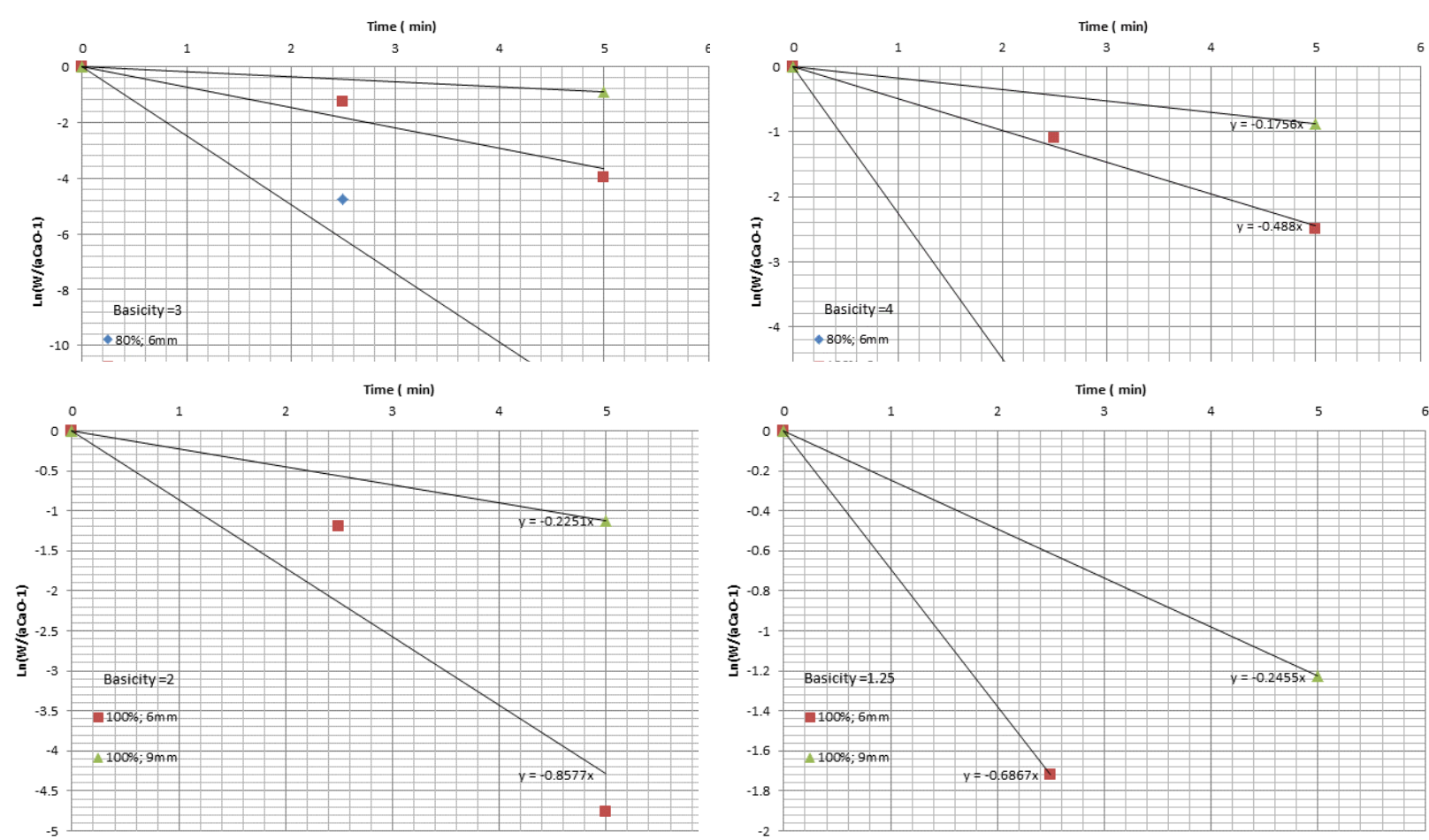

Figure 8: Prediction of kinetic coefficient $(k)$

Table VII: summary of statistical multi linear correlation

\begin{tabular}{|c|c|c|c|c|c|c|}
\hline \multirow[b]{2}{*}{ Effect } & \multicolumn{6}{|c|}{$\begin{array}{l}\text { Parameter Estimates (Spreadsheet1) } \\
\text { Sigma-restricted parameterization }\end{array}$} \\
\hline & $\begin{array}{c}\mathrm{k} \\
\text { Param. }\end{array}$ & $\begin{array}{c}\mathrm{k} \\
\text { Std.Err }\end{array}$ & $\begin{array}{l}k \\
t\end{array}$ & $\begin{array}{l}k \\
p\end{array}$ & $\begin{array}{l}-95.00 \% \\
\text { Cnf.Lmt }\end{array}$ & $\begin{array}{l}+95.00 \% \\
\text { Cnf.Lmt }\end{array}$ \\
\hline Intercept & -10.4465 & 0.459720 & -22.7235 & 0.000000 & -11.5714 & -9.32159 \\
\hline burning level & 8.6157 & 0.469657 & 18.3446 & 0.000002 & 7.4665 & 9.76488 \\
\hline basicity & 0.2615 & 0.135409 & 1.9310 & 0.101699 & -0.0699 & 0.59281 \\
\hline lump size & 1.4570 & 0.216554 & 6.7282 & 0.000525 & 0.9271 & 1.98691 \\
\hline
\end{tabular}




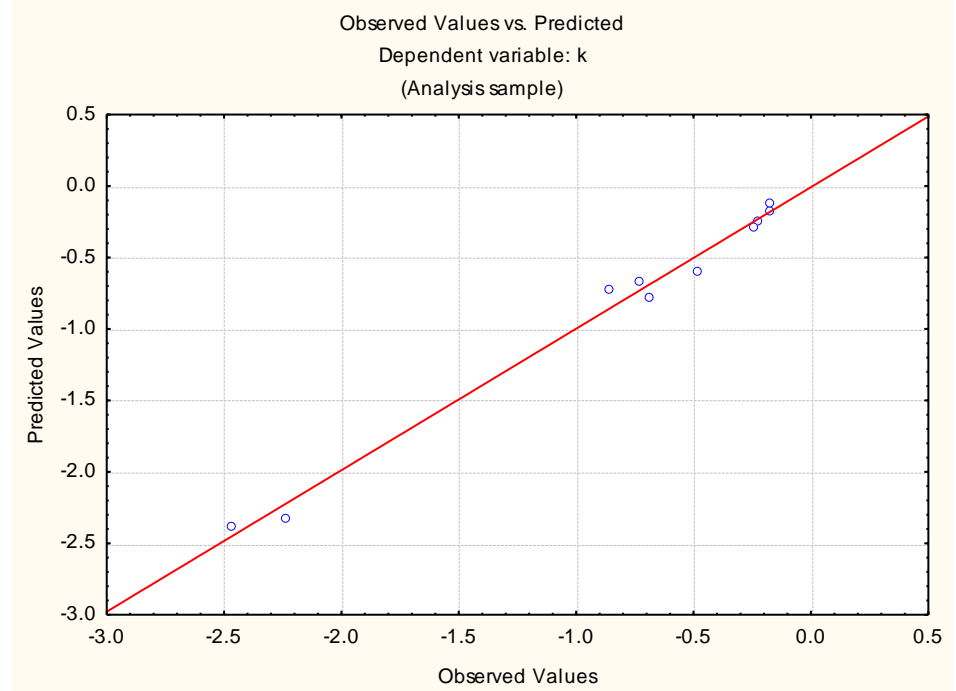

Figure 9: Fitness of the multilinear model of kinetic coefficient

From coefficients of table VII, reduction of calcination level or basicity or particle size would lead a lower "k" value which means a faster dissolution rate. As these variables were standardized between zero and one, we can notice that calcination level was the more influenced variable followed by particle size. Basicity showed weakest effect. This result suggests that lime-slag contact area seems to be more significant than viscosity in the lime dissolution process of present experiments.

As long as high basicity process is a restriction for BOF process, fast slag formation that requires fast lime dissolution would be regulated mainly by variables that determine lime-slag interfacial area (particle size; porosity and slag foaming) and $\mathrm{FeO}$ content, which would regulate viscosity at a certain temperature avoiding solid phase precipitations at early stage of slag formation. Temperature, itself is one of the most important variable that affects strongly slag formation: the highest one the better.

\section{CONCLUSIONS}

Tests results using lower lime calcination level did no reduced lime dissolution rate; on the contrary these tests reported a faster process than the others that used $100 \%$ Calcinated lime. These results can be attributed to some differences in lime porosity (higher in $80 \%$ Calcinated materials) or a foaming effect observed during the tests due to $\mathrm{CO} 2$ evolution of remaining calcination.

The increase of slag basicity resulted in reduction of lime dissolution rate, which can be attributed to a denser solid phase precipitation at the interface lime particle-slag that might increase slag viscosity as well reduce particle porosity.

Lime calcination level was the strongest effect on kinetic coefficient of lime dissolution process, followed by particle size. The weaker effect was from slag basicity. This result suggests that lime-slag contact area seems to be more significant than viscosity in the lime dissolution process of present experiments. 


\section{REFERENCES}

1 TANAKA T. OGISO, Y. UEDA, M. LEE, J. Trial on the Application of Capillary Phenomenon of Solid $\mathrm{CaO}$ to Desulfurization of Liquid Fe, ISIJ International, Vol. 50 (2010), No. 8, pp. 1071-1077

2 CICUTTI, C. VALDEZ, M. PÉREZ, T. PETRONI, J. GÓMES, A. DONAYO, R. FERRO, L. Sixth International conference on molten Slags, Fluxes and Salts, Stockholm-Helsinki, paper 367, 2000.

3 DENG, T. GRAN, J. SICHEN, D. Dissolution of Lime in Synthetic 'FeO'-SiO2 and $\mathrm{CaO}-' F e O '-S i O 2$ Slags, steel research int. 81 (2010) No. 5. 